\title{
PRINCIPAL'S TRANSFORMATIONAL LEADERSHIP AND TEACHERS' AFFECTIVE COMMITMENT IN PRIMARY CLUSTER SCHOOLS IN SELANGOR
}

\author{
Jeyasushma Veeriaha*, Chua Yan Piawa $^{\mathrm{a}}$, Siaw Yan Lia \\ a'Institute of Educational Leadership, University of Malaya, Malaysia \\ *Corresponding Author Email: sushma@siswa.um.edu.my
}

\begin{abstract}
Leadership quality exerted by school principals is undeniably a crucial constituent in ascertaining commitment among teachers. Furthermore, commitment among school teachers is closely associated to various duties and obligations, with an innovative attitude in the light of school development. As such, this study investigates the influence of principal transformational leadership practices on teacher affective commitment in primary cluster schools located in Selangor. This study employed a quantitative methodology using self-administered questionnaires on 331 teachers from primary cluster schools around Selangor. The findings indicted a statistically significant and positive moderate correlation between principal transformational leadership practices and teacher affective commitment. Multiple regression analysis revealed that strengthening school culture appears to be the sole dimension of transformational leadership that is statistically significant in predicting teacher affective commitment. Finally, the findings obtained from this study can function as a reference among school principals in determining the effect of transformational leadership, as well as the significance of strengthening school culture to boost teachers' affective commitment from the perspective of primary cluster schools in Selangor.
\end{abstract}

Keywords: Principal transformational leadership practices, teacher affective commitment, cluster schools 


\section{INTRODUCTION}

A sound educational system satisfies children's desire to learn and produces citizens with high intellect and moral integrity. Besides, education is also a valuable key asset for employment (Gerhard \& Hoelscher, 2017) and to generate innovative knowledge in boosting the nation's economic development (Sumintono, 2015).

Nonetheless, with the realisation that the educational system will constantly evolve, as well as the need to stay abreast with its progress, the Ministry of Education (MOE) of Malaysia has launched the Malaysia Education Blueprint (PPPM) $2013-2025$ in 2012. This blueprint suggests a sustainable transformation to the education system (Muhammad, Norfariza, Alina, \& Mojgan, 2013). Based on the blueprint, reformation of the education system will comprise of 11 shifts in order to be on par with developed nations and has to be carried out in three 'waves'. Of the 11 shifts, the fifth shift dictates high-performing leaders in schools (MOE, 2013, p. E-25).

Prior to this, the Ministry of Education had worked on accelerating excellence through educational institutions. One of it was the establishment of the Cluster Schools of Excellence (SKK) in 2006. It is a brand given to schools identified as being excellent in its cluster from the aspects of school management and student achievement. It was created to foster excellence in schools and to achieve a conducive teaching and learning environment within the Malaysian education system (MOE, 2012). The recognition was given cohort by cohort and is in accordance with the schools' niche area like academics, sports, music, and henceforth.

Therefore, there is a dire need for schools to have leaders who are able to bring about positive changes in schools in a systematic and continuous manner. Moreover, 
according to Pradhan and Pradhan (2015), leadership is indeed a vital motivation to improve the organization's performance. Besides, Robbins and Judge (2013) defined 'leadership' as the leaders' "ability to influence a group towards the achievement of a vision or set of goals" (p. 368). Leaders in schools play an essential role in assisting with the implementation of changes, starting from setting the directions for the goals until attaining them (Sharma, 2010). Hence, good leadership in schools helps to enhance the efficiency and the integrity of schooling.

In fact, the transformational leadership style has been deemed as the ideal school leadership (Berkovich, 2016; Jovanovic \& Ciric, 2016; Yang, 2014), particularly to overcome challenges in restructuring schools (Noraazian \& Khalip, 2016), such as to shape the vision to foster teacher empowerment (Kurland, Peretz, \& HertzLazarowitz, 2010). Transformational leaders are visionary leaders, who function as catalysts, besides being motivated, goal-oriented, and forward-looking to mould a better culture (Rolfe, 2011). Besides, Sabariah, Juninah @ Junainah, Khaziyati, and Salina (2010) claimed that transformational leaders encourages teachers to improvise their attitude and values, besides maintaining the desired level of commitment towards the goals set by the school. Bass (1985) also noted that transformational leaders are able to generate a higher level of commitment, trust, and inspiration among its followers, thus ascertaining performance beyond expectation. It is important to note that in Malaysia, the school leaders of primary schools are called headmasters or headmistress. For this study, the term principal is used to refer to them. 
Other than leadership, committed teachers are also an important factor in determining the success or failure of the education in schools. According to Zainudin, Junaidah, and Nazmi (2010), teachers are directly involved in the educational process, where they are responsible for equipping their students with knowledge and good ethics. In fact, organizational commitment, is a well-researched construct (Ahmad, Ather, \& Hussain, 2014), is defined as "a psychological state that binds an individual to the organization (i.e., makes turnover less likely)" (Allen \& Meyer, 1990, p. 14). Moreover, a committed employee is responsible, more involved, loyal, and possesses a sense of ownership towards the organization (Abubakar, Chauhan, \& Kura, 2015). This makes them the greatest asset in an organization, as commitment promotes positive outcomes (Hanaysha, 2016).

Prior studies have proven that effective leadership is the lifeline of an organization to achieve its goals and to increase employee commitment (Mareena, Norhasni, Ismi \& Azizan, 2011). Moreover, transformational leaders motivate their subordinates to be loyal towards the organization, whereby their commitment is based on their emotional attachment rather than on any logical calculation (Pradhan \& Pradhan, 2015). Therefore, this study had been carried out to determine the influence of principal transformational leadership style on teacher affective commitment in Selangor primary cluster schools.

Through this study, we can learn in depth the influence of principal's transformational leadership practices on teachers' commitment. The findings would also shed some light to the current and aspiring principals towards influencing and motivating teachers to work towards the pedagogy. Adding on, the study on cluster schools is 
important to the larger context of school improvement as it will contribute towards the establishment of cluster schools in the future and principals from the non-cluster schools would be able to learn and follow for improvement.

The following are the research questions of the study:

1. Is there a significant relationship between principal transformational leadership practices and teacher affective commitment among primary cluster schools in Selangor?

2. Which principal transformational leadership dimensions function as the significant predictors for teacher affective commitment among primary cluster schools in Selangor?

\section{PRINCIPAL'S TRANSFORMATIONAL LEADERSHIP}

According to Northouse (2013), leadership is all about providing directions, executing plans, and motivating people. Hence, the primary aspect of transformational leadership revolves around the subordinates' specific needs like motivation, ethical aspirations, empathy, support, and personal development (Kovjanic, Schuh, Jonas, Van Quaquebeke \& Van Dick, 2012; Rusliza \& Ebrahim, 2016), as well as increasing the subordinates' personal commitment towards the organizational goals (Leithwood \& Jantzi, 1999). Additionally, Bush (2014) asserted that transformational leadership is an essential leadership model and it has emerged as "the most popular approach in the present scholarly of leadership" (Tal \& Gordon, 2016, p. 267).

Transformational leadership was first initiated by Burns (1978), where the focus was on political leaders. He defined transformational leadership as the behaviour of 
leaders who "recognize and exploit an existing need or demand of a potential follower" (р. 4), thus looking further and identifying the "potential motives in followers, seeking to satisfy higher needs, and engaging the followers" (p. 4).

Later, this idea of transformational leadership was enhanced by other researchers like Bass (1985) and Leithwood (1994), who focused on educational settings. Bass (1985) had conceptualized the transformational leadership into four components, known as the four "I's. The four are intellectual stimulation, idealized influence, individual consideration, and inspirational motivation. His model also included transactional leadership.

Later on, Leithwood (1994) conceptualized transformational model along eight dimensions and the effects when applied to school settings. The eight dimensions, as defined by Leithwood and Sun (2012). The eight are builds a widely-shared vision, whereby leaders identify, develop, and articulate a shared vision or broad purpose for their schools that is appealing and inspiring to staff; develop school goals in which leader's stress on the importance of common purpose, and motivate their staff; holds high-performance expectation by expecting high-quality of professionalism from the staff.

Principals provides individualized support by listening and attending to the individual's opinions and needs and act as mentors for the teachers as well as supporting their professional development. The models behaviour dimension focuses on 'walking the talk' and providing a model of high ethical behaviour; leaders also build a cohesive school culture around a common set of values, that reflects the school vision as part of the strengthens school culture dimension; and finally, the 
builds collaborative structure dimension focuses on the establishing working conditions that facilitate staff collaboration for planning and professional growth among staff.

Luft (2012) defined transformational leadership as "the process of building commitment to organize objectives and then, empowering followers to accomplish those objectives" (p. 32). This means a transformational leader works towards developing the subordinates' potentials, higher needs, moralities, and motivations (Bass \& Avolio, 1994), besides encouraging development and changes (Basham, 2012). In fact, Basham (2012) added that transformational leadership is essential in the education sector in order to meet the ever-changing academic environment.

In addition, studies have also indicated that leadership has a direct effect upon teacher behaviours (Boberg \& Bourgeois, 2016; Chen, Cheng, \& Sato, 2017; Eyal \& Roth, 2011; Gkolia, Belias, \& Koustelios, 2014). Moreover, Alkahtani (2016) noted that "leadership style is the most prevalent factor that influences employees' attitudes and behaviours, including organizational commitment" (p. 23), where transformational leadership is suitable with the characteristics of an effective leader.

\section{TEACHERS' AFFECTIVE COMMITMENT}

Meyer and Allen (1991) had listed three types of commitment, which are affective commitment, normative commitment, and continuance commitment. Affective commitment is linked to organizational behaviour (Meyer, Stanley, Herscovitch, \& Topolnytsky, 2002). Hence, affective commitment is defined as a person's psychological or emotional connection to, identification with, and participation in an organization (Meyer \& Allen, 1997). In other words, Allen and Meyer (1996) defined 
it as "identification with, involvement in, and emotional attachment to the organization" (p. 253). This means, when employees have a sense of identification with the organization, they in return would be emotionally attached to the company, and are likely to be more involved with the organization's goals.

Further, Meyer et al., (2002) defined normative commitment as an employee's perceived obligation to remain in the organization. It refers to the employees' loyalty towards the organization. Continuance commitment denotes the costs involved if thy leave the organization (Meyer et al., 2002). This indicates the bond between the employee with the organization, and their desire to either continue to work or leave the organization.

This research focuses only affective commitment mainly due to its favourable outcomes for both employees and organizations (Stinglhamber, Marique, Caesens, Hanin, \& De Zanet, 2015; Meyer and Maltin, 2010), such as being emotionally bonded to the organization, enthusiasm, lower absenteeism, high job performance, less stress and a better balance between work and life (Meyer \& Allen, 1991).

\section{PRINCIPAL'S TRANSFORMATIONAL LEADERSHIP AND TEACHERS' AFFECTIVE}

\section{COMMITMENT}

Furthermore, Asrar-ul-Haq and Kuchinke (2016) reported that transformational leadership style enhances one's emotional attachment towards the organisation. Besides, Paul, Bamel, and Garg (2016) stated that "affective attachment allows employees to uphold the psychological contract with the organization to sustain organizational commitment" (p. 313). Thus, if teachers are emotionally committed to 
schools, they would be proud to be part of the school by exerting higher self-esteem and affective bonds (Sayğan, 2011).

Numerous studies have proven the correlation between transformational leadership and affective commitment. For example, a study conducted by Riaz, Akram, and ljaz (2011) upon 293 employees from the banking sector in Islamabad, Pakistan revealed a significantly positive relationship between transformational leadership and employees' affective commitment, as it was found that the transformational leadership style increased the level of affective commitment among the respondents.

Chou (2013), carried out a study on the members of Farmers' Associations in Taiwan, concluded that the behaviour displayed by leaders practising transformational leadership was indeed effective and emerged as compelling indicators for employees. Meanwhile, Jackson, Meyer, and Wang (2013) also found a strongly positive correlation between transformational leadership and affective commitment, where transformational leaders "use emotional appeals and create a compelling vision that make employees want to stay" (p. 94). In fact, similar results were obtained by Gao and Bai (2011) in their study on 186 family businesses in China, in which transformational leadership demonstrated a strong influence upon affective commitment.

Meanwhile, Nurharani, Norshidah, and Afni (2013) discovered that teachers in a daily secondary school located at Klang perceived that their principals exercised strong transformational leadership behaviour. Additionally, transformational leadership behaviour and organizational commitment portrayed a strong and positive ( $r=0.539$, 
$p=0.000$ ) linear correlation. Furthermore, the Pearson's Product Moment correlation coefficients revealed strong and significantly positive linear relationships between the four aspects of transformational leadership behaviour and organizational commitment. Moreover, their result is in line with that of Noordin, Mohd Rashid, Ghani, Aripin, and Darus (2010), who also discovered that most Malaysian teachers exerted a high level of affective commitment.

As such, Meyer and Allen (1991) claimed that teachers would display high level of affective commitment towards the school if they are provided with well-defined job descriptions. Hence, this study had been carried out to determine the influence of principals' transformational leadership on teachers' affective commitment in primary cluster schools in Selangor.

\section{METHODOLOGY}

The data were collected from a sample of teachers working in primary cluster schools located at Selangor. The simple random sampling procedure was employed, as this procedure allows an equal opportunity for each respondent in the population to be selected (Chua, 2011). With that, a total of 331 teachers out of 2,348 teachers were selected as respondents for this study.

The survey technique had been employed in order to gain data for the study. Hence, questionnaire with three parts had been distributed to the respondents. Part $A$ was on principal transformational leadership practices, Part B was on affective commitment, and Part C focused on the demographic background of the respondents. In addition, the aspect of principal transformational leadership was measured by 
using the Nature of School Leadership questionnaire, a 34 items questionnaire with eight transformational leadership dimensions.

The items were measured on an 11-point numerical rating scale, whereby 1 indicates Strongly Disagree and 11 indicates Strongly Agree. On the other hand, the affective commitment aspect was taken from the Organizational Commitment Questionnaire by Allen and Meyer (1990), which comprised of 6 items and measured on an 11-point numerical rating scale, whereby 1 indicates Strongly Disagree and 11 indicates Strongly Agree.

After all the questionnaires had been returned, the data obtained were analysed by using the Statistical Packages for the Social Sciences (SPSS) version 22.0. Descriptive analysis, such as frequency and percentage, was used for the demographic background of the respondents. Meanwhile, the correlation between principal transformational leadership practices and teachers' level of affective commitment was determined by using the Pearson product-moment correlation test, whereas multiple regression analysis was performed to identify the transformational leadership dimensions that functioned as significant predictors for teacher affective commitment.

\section{FINDINGS}

The findings of the study are presented in the following sections, beginning with the demographic profile and followed by explanation to answer the research questions. 


\section{Demographic Profile}

Table 1 presents the demographical background of the respondents pertaining to age, gender, qualification, and work experience. Majority of the respondents (54.4\%) belonged to the age bracket of 30-39 years old, $29.3 \%$ within the age range of $40-49$ years, $9.4 \%$ were below 30 years old, while only $6.9 \%$ of the respondents were above 50. Other than that, the table also shows that most of the respondents $(77.3 \%)$ were female, while the remaining $22.7 \%$ were male respondents.

In addition, slightly more than three-quarter of them (79.5\%) had completed their Bachelor degree, while $7.3 \%$ of them are Master's degree holders. On top of that, a total of $21(6.3 \%)$ teachers had completed their Diploma, followed by $1.8 \%$ with Sijil Pelajaran Malaysia (SPM), and $1.2 \%$ with Sijil Tinggi Pelajaran Malaysia (STPM). However, only one respondent ( $0.3 \%)$ had PhD qualification. Additionally, $36.6 \%$ of teachers had six to ten years of experience, while $22.7 \%$ had twenty years or more experience, and 61 (18.4\%) of them were in the category of 11 to 15 years. Lastly, the remaining 74 teachers were equally divided in the 1-5 and 16-19 years of experience.

Table 1: Demographic profile of respondents

\begin{tabular}{llcc}
\hline Demographic & Characteristics & Frequency & $\begin{array}{c}\text { Percentage } \\
\text { (\%) }\end{array}$ \\
\hline Gender & Male & 75 & 22.7 \\
& Female & 256 & 77.3 \\
& & & \\
Age & Below 30 years old & 31 & 9.4 \\
& 30-39 years old & 180 & 54.4 \\
& 40-49 years old & 97 & 29.3 \\
& 50 and above & 23 & 6.9
\end{tabular}




\begin{tabular}{llcc} 
Education level & Sijil Pelajaran Malaysia (SPM) & 6 & 1.8 \\
& Sijil Tinggi Pelajaran Malaysia & 4 & 1.2 \\
& (STPM) & & \\
& Teaching Certificate & 12 & 3.6 \\
& Diploma & 21 & 6.3 \\
& Bachelor Degree & 263 & 79.5 \\
& Master's Degree & 24 & 7.3 \\
Years of & PhD & 1 & 0.3 \\
experience as & 1-5 years & 37 & 11.2 \\
a Teacher & 11-15 years & 121 & 36.6 \\
& $16-19$ years & 61 & 18.4 \\
& 20 years & 37 & 11.2 \\
& & 75 & 22.7 \\
\hline
\end{tabular}

Relationship between principal transformational leadership practices and teacher affective commitment

To determine is there a significant relationship existed between principal transformational leadership practices and teacher affective commitment in primary cluster schools at Selangor, Pearson product-moment correlation test was carried out. The results of the analysis are presented in Table 2.

Table 2: Pearson product-moment correlation analysis between principal transformational leadership practices and teacher affective commitment

\begin{tabular}{llc}
\hline Variable & Statistics & Affective Commitment \\
\hline Principal Transformational & Pearson Correlation & $.443^{* *}$ \\
Leadership Practices & Sig (2-tailed) & .000 \\
& $\mathrm{~N}$ & 331
\end{tabular}

** Correlation is significant at the 0.01 level (2-tailed)

The Pearson correlation analysis indicated that teachers from primary cluster schools in Selangor perceived a statistically significant and positive correlation between 
principal transformational leadership practices and teacher affective commitment at a moderate level $(r=0.443, p<.001)$. This positive relationship reflects that when principals practice a higher level of transformational leadership, an increment in the level of teacher affective commitment can be noted.

\section{Predictors of teacher affective commitment}

Next, to determine the significant dimensions of the principal transformational leadership that function as predictors of teachers' affective commitment among primary cluster schools in Selangor, the multiple regression analysis (stepwise) test had been employed.

As a result, Table 3 shows that out of the eight dimensions of principal transformational leadership practices, only strengthening school culture dimension contributed significantly (21.0\%) to teachers' affective commitment among primary cluster schools located at Selangor. On top of that, the results obtained from the ttest were also significant $(\beta=0.458, t=9.350, p=0.000)$. The standardised beta value indicated that when strengthening school culture dimension increased by 1 unit of standard deviation, the aspect of teacher affective commitment also increased, but by 4.58 units of standard deviation. Therefore, a significant relationship does exist between principal transformational leadership practices and teacher affective commitment $(p=0.000<.05)$.

Table 4 presents the F-test results, which revealed a significant correlation between the predicting variable and teacher affective commitment $[F(1,329)=87.430, p<$ 0.05] at a significant level of $p<0.05$. The multiple regression analysis also showed 
that the strengthening school culture dimension accounted for $21.0 \%$ of the variance in teachers' affective commitment. This shows that as much as $79 \%$ of the variance on teachers' affective commitment is unable to be predicted by principal transformational leadership practices, which might be due to other factors that were not examined in this study.

Table 3: Multiple regression (stepwise) on principal transformational leadership practices and teacher affective commitment

\begin{tabular}{|c|c|c|c|c|c|c|}
\hline Variable & & B & $\beta$ & $\mathrm{t}$ & Sig. & $\mathrm{R}^{2}$ \\
\hline $\begin{array}{l}\text { Strengthening } \\
\text { culture }\end{array}$ & school & 0.447 & 0.458 & 9.350 & 0.000 & 0.210 \\
\hline Constant & & 3.990 & & 8.947 & 0.000 & \\
\hline
\end{tabular}

Table 4: Multiple regression analysis (stepwise): ANOVA

\begin{tabular}{llllll}
\hline & Sum of Square & $\mathrm{df}$ & Mean Square & $\mathrm{F}$ & Sig \\
\hline Regression & 184.171 & 1 & 184.171 & 87.430 & 0.000 \\
Residual & 693.040 & 329 & 2.107 & & \\
Total & 877.211 & 330 & & & \\
\hline
\end{tabular}

\section{DISCUSSION}

The results of this study revealed a significant correlation between principal transformational leadership practices and teachers' affective commitment. Furthermore, the Pearson product-moment correlation value displayed moderate strength $(r=0.443, p<.001)$, which is in agreement with the studies carried out by Riaz et al., (2011), Keskes (2014), and Gulluce, Kaygin, Kafadar, and Atay (2016).

Nevertheless, the findings retrieved from the present study do differ from a study conducted by Jackson, Meyer, and Wang (2013), which revealed a rather strong 
correlation between transformational leadership and affective commitment. Perhaps, this could be due to other factors, for instance, classes taught, the nature of certain subjects, and workload as burden.

This finding matches with the literature that asserts principals who practice the transformational leadership style have a positive influence upon the aspect of affective commitment among teachers towards the school. Furthermore, the capability of these principals to set widely-shared vision and school goals that demonstrates high performance expectations, eventually, models the right behaviour and offers support for teachers. This determines the emotional feel experienced by teachers towards the school as an organization. Thus, it is essential for principals to adopt and practice the transformational leadership style in their relationship with their teachers. This is mainly because emotional attachment is increased between the teachers and the school.

Moreover, this study also revealed that only the dimension of strengthening school culture appeared to be the predictor of affective commitment, which demonstrated a significant contribution $(21.0 \%)$ to teacher's affective commitment among primary cluster schools located at Selangor. This is also in line with the conclusion purported by Kiral and Kacar (2016) that school culture does play a vital role in the level of commitment exerted by teachers. In fact, a healthy and positive school culture offers the teachers the sense of belonging (Kiral \& Kacar, 2016). Henceforth, it is significant to establish a favourable school culture that suits all. 
This result also corroborates with that obtained by Kiral and Kacar (2016), who stated that one of the most significant school-based factors that strongly affect the level of teacher's commitment is indeed school culture. This result also supports the research finding retrieved by Karadağ, Baloğlu, and Çakir (2011), who noted that "school culture depends on the sharing level of basic beliefs and values among its members" (p. 574), as well as Raharjo (2012), who claimed that school culture and leadership are inseparable.

Additionally, according to $\mathrm{Yu}$, Leithwood, and Jantzi (2002), strengthening school culture is reflective of the behaviour exerted by leaders, which contributes to the commitment of level of the teachers through the understandings of the school goals and its importance. This is justified in the findings of the present study, which indicated that the culture of strengthening school acts as a key predictor of teacher affective commitment. Hence, an effective principal would not only "bring a change in the perception of their followers towards work by attaching societal or organizational significance to it (Pradhan \& Pradhan, 2015, p. 232), but also to enhance the school culture.

On top of that, Masouleh and Allahyari (2017) stressed on the significance of employees' organisational culture and commitment and asserted that they should be put at the right level. This finding is in line with that obtained by Pradhan and Pradhan (2015). This is because; the significance for schools to have a strong school culture is beyond doubt to prevent internal conflict, as well as to enhance the overall commitment portrayed by teachers. This result also reflects that the relationship between principals and teachers appears to be the key factor to ascertain that the 
school goals are met. As such, principals need to be proactive and supportive so that teachers would have the desire to continue teaching, particularly at that school. Moreover, teachers with high emotional attachment to the school would demonstrate effective and successful teaching.

\section{IMPLICATIONS}

The findings of this study showed that principal transformational leadership practices are significantly correlated with teachers' affective commitment at a moderate strength. This supports the literature that principal transformational leadership practices have positive influence on teacher affective commitment. The study also contributes a better understanding of principals' transformational leadership practices and how it effects teachers' affective commitment at primary cluster schools located at Selangor. This in turn would help principals and future principals to refine their leadership style towards transformational leadership style to enhance their leadership effect on teachers and school.

Among the eight dimensions of transformational leadership, only the strengthening school culture dimension contributed in explaining the variation in teachers' affective commitment. But the effects were not strong. According to Leithwood and Sun (2012) the strengthening school culture behaviour by the principals will help teachers to understand the school's vision and goals, which in turn will increase teachers' commitment.

Therefore, principals should practice being transformational leaders in order to increase teachers' affective commitment. In doing so, principals must be attuned to 
the feelings and needs of the teachers, while at the same time communicate the school's visions and goals. Such encouraging practices will motivate teachers to have a stronger emotional bond towards their schools.

Finally, this study provides information for the Ministry of Education, existing and aspiring principals regarding leadership practices at the primary cluster schools at Selangor. This will assist them to plan the appropriate leadership training programme to develop effective leaders in schools. In addition, to enhance the effectiveness of leadership, principals should work on the other seven dimensions to increase teachers' affective commitment.

\section{CONCLUSION}

Affective commitment has a pivotal role in schools to determine its effectiveness and the outcome generated by the students. This is particularly significant for teachers are fundamental and paramount in carrying out the goals associated to teaching (Mart, 2013). Moreover, as vividly depicted in the literature, leadership plays an important role in schools especially to ensure that teachers maintain their commitment towards the schools. In fact, the dire need for reliable leaders in schools has been clearly outlined in the Malaysia Education Blueprint 2013 - 2025, which further elaborates on ascertaining high-performing school leaders, if possible, in each and every school (MOE, 2013, p. E-25).

In line with that, the results obtained from this study have highlighted the importance of transformational leadership in enhancing teachers' affective commitment. On top of that, this study supports the findings reported in prior studies, namely by Gulluce 
et al. (2016); Nurharani et al. (2013), as well as Khasawneh, Omari, and Abu-Tineh (2012).

In conclusion, this study would like to stress that the practice of transformational leadership style by principals is indeed vital as it is an imminent key aspect that increases the aspect of affective commitment among teachers. Other than that, the findings of the present study offers insight from the perspective of primary cluster schools, hence paving a direction for future studies. Moreover, it is recommended that future studies should look into more cluster schools from various states with mixed-method data collection. 


\section{REFERENCES}

Abubakar, R. A., Chauhan, A., \& Kura, K. M. (2015). The relationship between human resource management practices and employee's turnover intention among registered nurses in Nigerian public hospitals: The mediating role of organisational trust. Sains Humanika, 5(2), 95-98. doi: org/10.11113/sh.v5n2.636

Ahmad, J., Ather, M. R., \& Hussain, M. (2014, June). Impact of Big Five personality traits on job performance (Organizational commitment as a mediator). Paper presented at the Management, Knowledge and Learning International Conference 2014, Portorož, Slovenia.

Alkahtani, A. H. (2016). The influence of leadership styles on organizational commitment: The moderating effect of emotional intelligence. Business and Management Studies, 2(1), 23-34.

Allen, N. J., \& Meyer, J. P. (1990). The measurement and antecedents of affective, continuance and normative commitment to the organization. Journal of Occupational and Organizational Psychology, 63(1), 1-18. doi: 10.1111/j.20448325.1990.tb00506.x

Allen, N. J., \& Meyer, J. P. (1996). Affective, continuance and normative commitment to the organization: An examination of construct validity. Journal of Vocational Behaviour, 49 (3), 252-276. 
Asrar-ul-Haq, M., \& Kuchinke, K. P. (2016). Impact of leadership styles on employees' attitude towards their leader and performance: Empirical evidence from Pakistani banks. Future Business Journal, 2 (1), 54-64.

Basham, L. M. (2012). Transformational and transactional leaders in higher education. S.A.M. Advanced Management Journal, 77(2), 15-23.

Bass, B. M. (1985). Leadership and performance beyond expectation. New York, NY: The Free Press.

Bass, B. M., \& Avolio, B. J. (1994). Improving organizational effectiveness through transformational leadership. Thousand Oaks, CA: Sage

Berkovich, I. (2016). School leaders and transformational leadership theory: Time to part ways? Journal of Educational Administration, 54(5), 609-622.

Boberg, J. E., \& Bourgeois, S. J. (2016). The effects of integrated transformational leadership on achievement. Journal of Educational Administration, 54(3), 357-374. doi:org/10.1108/JEA-07-2014-0086

Burns, J. M. (1978). Leadership. New York, NY: Harper \& Row Publishers.

Bush, T. (2014). Instructional and transformational leadership: Alternative and complementary models? Educational Management Administration and Leadership, 42(4), 443-444.

Chen, Y.-G., Cheng, J.-N., \& Sato, M. (2017). Effects of school principals' leadership behaviors: A comparison between Taiwan and Japan. Educational Sciences: Theory \& Practice, 17(1), 145-173. doi:10.12738/estp.2017.1.0018 
Chou, P. (2013). The effect of transformational leadership on follower's affective commitment to change. World Journal of Social Sciences, 3(1), 38-52.

Chua, Y. P. (2011). Kaedah dan Statistik Penyelidikan, Buku 1, Kaedah Penyelidikan (Edisi Kedua). Kuala Lumpur: Mc Graw Hill.

Eyal, O., \& Roth, G. (2011). Principals' leadership and teachers' motivation. Journal of Educational Administration, 49(3), 256-275. doi:10.1108/09578231111129055

Gao, F. Y., \& Bai, S. (2011). The effects of transformational leadership on organisational commitment of family employees in Chinese family business. International Proceedings of Economics Development and Research, 7, 43-48.

Gerhard, U. \& Hoelscher, M. (2017). Knowledge makes cities: Education and knowledge in recent urban development. The case of Heidelberg, Germany. In U. Gerhard, M. Hoelscher, \& D. Wilson (Eds.), Inequalities in Creative Cities: Issues, Approaches, Comparisons (pp. 129-164). New York, NY: Palgrave-Macmillan

Gkolia, A., Belias, D., \& Koustelios, A. (2014). The impact of principals' transformational leadership on teachers' satisfaction: Evidence from Greece. European Journal of Business and Social Sciences, 3(6), 69-80

Gulluce, A. Ç., Kaygin, E., Kafadar, S. B., \& Atay, M. (2016). The relationship between transformational leadership and organizational commitment: A Study on bank employees. Journal of Service Science and Management, 9, 263-275. doi: $10.4236 / j s s m .2016 .93033$ 
Hanaysha, J. (2016). Testing the Effects of Employee Engagement, Work Environment, and Organizational Learning on Organizational Commitment. Procedia-Social and Behavioral Sciences, 229, 289 - 297. doi: 10.1016/j.sbspro.2016.07.139

Jackson, T. A., Meyer, J. P., \& Wang, X. (2013). Leadership, commitment, and culture: A meta-analysis. Journal of Leadership \& Organizational Studies, 20(1), 84-106.

Jovanovic, D., \& Ciric, M. (2016). Benefits of transformational leadership in the context of education. The European Proceedings of Social \& Behavioural Sciences, $15,496-503$

Karadağ E., Baloğlu,N., \& Çakir, A. (2011). A path analysis study of school culture and teachers' organisational commitment. Policy Futures in Education, 9(5), 573-584.

Keskes, I. (2014). Relationship between leadership styles and dimensions of employee organizational commitment: A critical review and discussion of future directions. Intangible Capital, 10(1), 26-51. doi:10.3926/ic.476

Khasawneh, S., Omari, A., \& Abu-Tineh, A. M. (2012). The relationship between transformational leadership and organizational commitment: The case for vocational teachers in Jordan. Educational Management Administration \& Leadership, 40(4), 494-508. doi:10.1177/1741143212438217

Kiral, E., \& Kacar, O. (2016). The relationship between teachers' school commitment and school culture. International Education Studies, 9(12), 90-108. doi:10.5539/ies.v9n12p90 
Kovjanic, S., Schuh, S. C., Jonas, K., Van Quaquebeke, N., \& Van Dick, R. (2012). How do transformational leaders foster positive employee outcomes? A selfdetermination-based analysis of employees' needs as mediating links. Journal of Organizational Behavior, 33(8), 1031-1052. doi: org/10.1002/job.1771

Kurland, H., Peretz, H., \& Hertz-Lazarowitz, R. (2010). Leadership style and organizational learning: The mediate effect of school vision. Journal of Educational Administration, 48(1), 7-30.

Leithwood, K. (1994). Leadership for school restructuring. Education Administration Quarterly, 30(4), 498-518. doi:10.1177/0013161X94030004006

Leithwood, K., \& Jantzi, D. (1999). Transformational school leadership effects: A replication. School Effectiveness and School Improvement, 10(4), 451-479.

Leithwood, K., \& Sun, J. (2012). The nature and effects of transformational school leadership: A meta-analytic review of unpublished research. Educational Administration Quarterly, 48(3), 387-423. doi:10.1177/0013161×11436268

Luft, K. A. (2012). A research study of transformational leadership comparing leadership styles of the principal. (Doctoral dissertation, Duquesne University). Retrieved from http://www.duq.edu/Documents/education/_pdf/DEFL/dissertations/2012030 9-luft.pdf

Mareena, M., Norhasni, Z. A., Ismi, I., \& Azizan, H. (2011). Tinjauan hubungan gaya kepimpinan dengan komitmen organisasi. Jurnal Eksplanasi, 6(1), 17-28. Retrieved from http://merr.utm.my/id/eprint/4862 
Mart, C. T. (2013). Commitment to school and students. International Journal of Academic Research in Business and Social Sciences, 3(1), 336-340. Retrieved from https://pdfs.semanticscholar.org/bbf9/542e25680fff58006ecf86a989c94de5b9 43.pdf

Masouleh, Z. D., \& Allahyari, M. S. (2017). The predictability of organisational culture for commitment among faculty members: evidence from Iran higher education. International Journal of Management in Education, 11(1), 94-109. doi:10.1504/IJMIE.2017.080660

Meyer, J. P., \& Allen, N. J. (1991). A three-component conceptualization of organizational commitment. Human Resource Management Review, 1(1) 61-89

Meyer, J. P., \& Allen, N. J. (1997). Commitment in the workplace: Theory, research and application. Thousand Oaks, CA: Sage Publications.

Meyer, J. P., Stanley, D. J., Herscovitch, L., \& Topolnytsky, L. (2002). Affective, continuance, and normative commitment to the organization: A meta-analysis of antecedents, correlates, and consequences. Journal of Vocational Behavior, $61(1), 20-52$

Meyer, J. P., \& Maltin, E. R. (2010). Employee commitment and wellbeing: a critical review, theoretical framework and research agenda. Journal of Vocational Behavior, 77 (2), 323-337. doi.org/10.1016/j.jvb.2010.04.007

Ministry of Education Malaysia. (2012). Cluster School of Excellence. Retrieved from http://www.moe.gov.my/en/sekolah-kluster-kecemerlangan 
Ministry of Education Malaysia. (2013). Malaysia Education Blueprint 2013-2025: Preschool to Post-Secondary Education. Putrajaya: Ministry of Education Malaysia.

Muhammad, F. A. G., Norfariza, M. R., Alina, R., \& Mojgan, A. (2013). Educational Management in Malaysia. Kuala Lumpur: University of Malaya Press.

Noordin, F., Mohd Rashid, R., Ghani, R., Aripin, R., \& Darus, Z. (2010). Teacher professionalisation and organisational commitment: Evidence from Malaysia. International Business \& Economics Research Journal, 9(2), 49-58

Noraazian, O., \& Khalip, M. (2016). The impact of transformational leadership and teacher commitment in Malaysian public schools. International Journal of Academic Research in Business and Social Sciences, 6(11), 388-397. doi: 10.6007/IJARBSS/v6-i11/2407

Northouse, P. G. (2013). Leadership, theory and practice (5th ed.). Thousand Oaks, CA: Sage.

Nurharani, S., Norshidah, N., \& Afni, A. A. (2013). Rekindle teacher's organizational commitment: The effect of transformational leadership behavior. Procedia Social and Behavioral Sciences, 90, 566-574. doi: 10.1016/j.sbspro.2013.07.127

Paul, H., Bamel, U. K. \& Garg, P. (2016). Employee Resilience and OCB: Mediating Effects of Organizational Commitment. Vikalpa: The Journal for Decision Makers, 41(4), 308-324. doi: 10.1177/0256090916672765 
Pradhan, S., \& Pradhan, R. K. (2015). An Empirical Investigation of Relationship among Transformational Leadership, Affective Organizational Commitment and Contextual Performance. Vision, 19(3), 227-235. doi: $10.1177 / 0972262915597089$

Raharjo, N. E. (2012). Principal role in strengthening the school culture of vocational high school. Paper presented at International Conference on Vocational Education and Training (ICVET) 2012, Yogyakarta State University, Indonesia.

Riaz, T., Akram, M. U. \& ljaz, H. (2011). Impact of Transformational Leadership Style on Affective Employees'commitment: An Empirical Study of Banking Sector in Islamabad (Pakistan). The Journal of Commerce, 3(1), 43-51.

Robbins, S. P., \& Judge, T. A. (2013). Organizational behavior (15th ed.). Upper Saddle River, New Jersey: Pearson Education, Inc.

Rolfe, P. (2011). Transformational leadership theory: What every leader needs to know. Nurse Leader, 9(2), 54-57. doi: org/10.1016/j.mnl.2011.01.014

Rusliza, Y., \& Ebrahim, F. (2016). Leadership styles and organizational commitment: literature review. Journal of Management Development, 35(2), 190 - 216. doi: 10.1108/JMD-01-2015-0004

Sabariah, S., Juninah @ Junainah, D., Khaziyati, O., \& Salina, S. (2010). Headmaster's leadership style and teachers' commitment in Malaysian rural primary schools. The International Journal of Learning, 16(12), 229-244. Retrieved from http://eprints.ums.edu.my/3907/ 
Sayğan, F. N. (2011). Relationship between affective commitment and organizational silence: A conceptual discussion. International Journal of Social Sciences and Humanity Studies, 3(2), 219-227.

Sharma, S. (2010). Perceived leadership capacities of Malaysian school principals. International Journal of Educational Administration, 2(3), 335-348 Retrieved from http://repository.um.edu.my/8593/1/New\%20Resaerch\%20paper.pdf

Stinglhamber, F., Marique, G., Caesens, G., Hanin, D., \& De Zanet, F. (2015). The influence of transformational leadership on followers' affective commitment. The role of perceived organizational support and supervisor's organizational embodiment. Career Development International, 20(6), 583 - 603. doi: 10.1108/CDI-12-2014-0158

Sumintono, B. (2015, October). Science education in Malaysia: challenges in the 21st century. Paper presented at the 1st International Seminar on Science Education (ISSE), Universitas Negeri Yogyakarta, Yogyakarta, Indonesia.

Tal, D. \& Gordon, A. (2016). Leadership of the present, current theories of multiple involvements: a bibliometric analysis. Scientometrics ,107(1), 259-269. doi:10.1007/s11192-016-1880-y

Yang, Y. (2014). Principals' transformational leadership in school improvement. International Journal of Educational Management,28(3),279-288. doi:org/10.1108/IJEM-04-2013-0063 
Yu, H., Leithwood, K., \& Jantzi, D. (2002). The effects of transformational leadership on teachers' commitment to change in Hong Kong. Journal of Educational Administration, 40(4), 368-389. doi:10.1108/09578230210433436

Zainudin, A., Junaidah, H. A., \& Nazmi, M. Z. (2010). Modelling job satisfaction and work commitment among lecturers: A case of UiTM Kelantan. Journal of Statistical Modeling \& Analytics, 1(2), 45-59. 